\title{
Breast disease in young West Indian women: an analysis of 1051 consecutive cases
}

\author{
G.C. Raju, N. Jankey and V. Naraynsingh \\ Departments of Pathology and Surgery, Port of Spain General Hospital, Trinidad, West Indies.
}

\begin{abstract}
Summary: Our analysis of 1051 breast biopsies in West Indian women under the age of $30 \mathrm{y}$ revealed that $99 \%$ of the breast lumps were benign. Fibroadenoma was the commonest $(67 \%)$ lesion and there was a steady increase in the frequency of fibrocystic disease with age. Carcinoma in this group is therefore rare. Thus most patients can be reassured with certainty of their benign disease and have biopsy at a convenient time.
\end{abstract}

\section{Introduction}

Breast cancer is the most common malignant disease and is the leading cause of death from cancer in women (Waterhouse et al., 1982). Since the presence of any breast mass raises the question of carcinoma, many young women are concerned about lumps in their breasts. We reviewed our experience with breast biopsies in young West Indian women in Trinidad in order to determine the pattern of breast disease in women under 30 years of age.

\section{Patients and methods}

A consecutive group of breast biopsies in women, predominantly Negro $(43 \%)$ and Indian $(41 \%)$ with less than $1 \%$ whites, under 30 years of age, seen at Port of Spain General Hospital, Trinidad, over a period of $6 y$ (1976-81) formed the basis of this study. The relevant details were noted from the patient's charts and pathology files. All histological sections from these cases were re-examined.

\section{Results}

During the study period 2,256 diagnostic breast biopsies were performed. Of these $1051(47 \%)$ were in women under 30 years of age. The age distribution and histological diagnoses of the breast lesions are shown in Table I. The youngest patient was $11 \mathrm{y}$ and the majority were between 16 and $25 \mathrm{y}$.

The commonest presenting complaint was a pain-

Correspondence: G.C. Raju, M.D., F.C.A.P., 15 Wainwright Street, St. Clair, Port of Spain, Trinidad, West Indies.

Accepted: 3 April 1985 less mass. The masses had been present 1-60 months (mean 14 months) before medical consultation. There was no difference in the side of involvement (left breast $48 \%$ and right breast $47 \%$ ) and bilaterality was noted in $5 \%$ of the cases.

Fibroadenoma was the most common histological diagnosis (67\%). The age range was $11-30 y$ with a peak in the $16-20 \mathrm{y}$ age group. The occurrence of fibroadenoma decreased with age. They were classical fibroadenoma histologically. Cysts and apocrine metaplasia were seen in $15 \%$ of these cases and epithelial hyperplasia in $8 \%$. Infarction of fibroadenoma was seen in 8 cases.

Fibrocystic disease was the next commonest condition $(29 \%)$. The age range was $14-30 y$ and the frequency of fibrocystic disease increased with age. The major histological components were cysts, duct ectasia, apocrine metaplasia and periductal mastitis. Sclerosing adenosis was seen in $3 \%$ of these cases; ductal and lobular hyperplasia was seen in $10 \%$ and $2 \%$ respectively.

Carcinoma was seen in $12(1.1 \%)$ cases. The youn-

Table I Age distribution and histological diagnoses of 1051 breast lesions

\begin{tabular}{lrrrrrr}
\hline & \multicolumn{7}{c}{ Age group in years } \\
& $11-15$ & $16-20$ & $21-25$ & $26-30$ & $n$ & $\%$ \\
\hline Fibroadenoma & 70 & 349 & 193 & 92 & 704 & 67 \\
Fibrocystic & 27 & 73 & 103 & 103 & 306 & 29 \\
Abscesses & 5 & 7 & 3 & 10 & 25 & 2.4 \\
Carcinoma & - & - & 2 & 10 & 12 & 1.1 \\
Fat necrosis & - & - & 1 & 1 & 2 & \\
Granular cell tumour & - & 1 & 1 & - & 2 & \\
\hline
\end{tabular}


gest patient was $23 \mathrm{y}$ and the majority were over the age of $26 \mathrm{y}$. Seven patients had infiltrating ductal carcinomas with regional lymph-node involvement. Two were circumscribed infiltrating ductal carcinomas, two intraductal carcinomas, and one Bowen's disease with infiltrating ductal carcinoma.

The other mammary diseases in this age group were non-specific abscesses in $25(2.4 \%)$, fat necrosis (2) and granular cell tumour (2).

\section{Discussion}

There is a general agreement in clinical and epidemiological publications concerning the age distribution of benign breast disease. Fibroadenomas occur at an earlier age, whereas fibrocystic disease is found to increase with age (Cole et al., 1978). Fibroadenoma of the breast as a disease of youth is the most frequent tumour in young women under the age of $25 \mathrm{y}$ (Haagensen, 1971; Nigro \& Organ, 1976; Oluwole \& Freeman, 1979; Ligon et al., 1980). The gross and microscopic features of fibroadenoma are usually characteristic. However, infarction occurring in a fibroadenoma can be clinically mistaken for carcinoma (Robitaille et al., 1974). An awareness of this infrequent complication will avoid unnecessary mastectomy. Since the epithelial component of fibroadenoma is presumably subject to the same biological stimuli as the breast epithelium in general, carcinoma might originate occasionally within fibroadenoma (Haagensen, 1971). None of our cases showed evidence of carcinoma, although epithelial

\section{References}

ACKERMAN, L.V. (1974). In Surgical Pathology, 5th Ed. p. 895 C.V. Mosby: St. Louis.

COLE, P., ELWOOD, J.M. \& KAPLAN, S.D. (1978). Incidence rates and risk factors of benign breast neoplasms. American Journal of Epidemiology, 108, 112.

ELLIS, H. \& COX, P.J. (1984). Breast problems in 1,000 consecutive referrals to surgical out-patients. Postgraduate Medical Journal, 60, 653.

ERNSTER, V. (1982). The epidemiology of benign breast disease. Epidemiology Review, 3, 184.

HAAGENSEN, C.D. (1971). In Diseases of the Breast, 2nd Ed. p. 213 W.B. Saunders: Philadelphia.

LIGON, R.E., STEVENSON, D.R., DINER, W., WESTBROOK, K.C. \& LANG, N.P. (1980). Breast masses in young women. American Journal of Surgery, 140, 779.

LOGAN, C.T.H. (1978). Carcinoma of the breast in women under the age of 30. British Medical Journal, 2, 1023.

MCCRACKEN, M., HAMAL, P.B. \& BENSON, E.A. (1979). Granular cell myoblastoma of the breast - a report of 2 cases. British Journal of Surgery, 66, 819.

NIGRO, D.M. \& ORGAN, C.H. (1976). Fibroadenoma of the hyperplasia was observed in $8 \%$ of fibroadenomas.

Fibrocystic disease of the breast is seen most frequently between 25 and 45 years of age (Oluwole \& Freeman, 1979; Ackerman, 1974). Certain epithelial proliferations in fibrocystic disease have been associated with an increased risk for the development of breast cancer (Ernster, 1981; Schuerch et al., 1982). In our study there is a steady increase in the frequency of fibrocystic disease with age and epithelial hyperplasia was seen in $10 \%$ of the cases.

Carcinoma of the breast under the age of $30 \mathrm{y}$ is rare (Taasdale \& Baum, 1976; Logan, 1978). However. Purandare \& Finbow (1978) quote an incidence of $5.1 \%$. Ligon et al. (1980) noted $2 \%$ of breast cancer in their study of breast masses in women under the age of 30. In a predominantly white population, of 1,000 consecutive referrals with breast complaints to outpatients' clinic, no patient under the age of 27 had carcinoma (Ellis \& Cox, 1984). In our study, $1 \%$ of breast disease in this age group was carcinoma and none occured in a woman under 23 years of age.

However, other conditions may mimic carcinoma. Though suppurative mastitis is becoming less common, a localized abscess may resemble carcinoma clinically (Ackerman, 1974). Granular cell tumours may be mistaken for cancer in clinical, mammographic and naked eye appearances, but these rare neoplasms have characteristic histological features (McCrackero et al., 1979). Although the chance of a breast lump being a carcinoma in this age group is only in the region of $1 \%$ only urgent biopsy can make this diagnosis. Thus, every woman with a discrete breast mass, regardless of age, warrants early investigation.

female breast: some epidemiologic surprises. Postgraduate Medicine, 59, 113.

OLUWOLE, S.F. \& FREEMAN, H.P. (1979). Analysis of benign breast lesions in blacks. American Journal of Surgery, 137, 786.

PURANDARE, A.S. \& FINBOW, J. (1978). Carcinoma of the breast in women under the age of 30. British Medical Journal, 2, 771.

ROBITAILLE, Y., SEEMAYER, T.A., THELMO, W.L. \& CUMBERLIDGE, M.C. (1974). Infarction of mammary region mimicking carcinoma of the breast. Cancer, 33, 1183.

SCHUERCH, C., III, ROSEN, P.L.P., HIROTA, T., ITABASHI, M., YAMAMOTO, H., KINNE, D.W. \& BEATTIE, E.J. (1982). A pathologic study of benign breast disease in Tokyo and New York. Cancer, 50, 1899.

TAASDALE, C. \& BAUM, M. (1976). Breast cancer in a school girl. Lancet, ii, 627.

WATERHOUSE, J., MUIR, C., SHANMUGARATNAM, K. \& POWELL, J. (1982). In Cancer Incidence in Five Continents, volume IV. IARC: Lyon, France. 